\title{
EVOLUTION OF THE GENERAL ROCK SCHEME IN IOWA.
}

\section{BY CHARLES KEYES.}

In at least one of the great branches of science Iowa happens to play a singularly unexpected but important role. On the historical side of carth-study our State chances to occupy a quite unique place. In three grand advancements of this science in this country the same western commonwealth takes an initial and leading part, and each time precedes sister states of the Union by a full generation. 'This in itself is a noteworthy fact concerning us. The purely scientific aspects of these circumstances need not be dwelt upon here; but from a strictly historical angle the incidents really deserve more than passing notice.

The first of these great forward steps in American earthscience took place in Towa more than a quarter of a century before she had become a state and long before even her name had been proposed.'

Chance sent an Englishman, Thomas Nuttall by name, to our shores, to the banks of the Mississippi river, where the principles of the then new modern science of geology were applied for the first time on the American continent.

As is quite generally known, the modern science of geology is yet scarcely more than a hundred years old. Its birth dates only from the opening days of the Nineteenth century, the time when it first became possible to read in the rocks a sequence of geologic events and to parallel the rock records of different parts of the world. This "Rosetta Stone" is William Smith's famous discovery that the relative age and natural succession of rock-layers were, by means of their coritained organic remains, susceptible to accurate determination.

Before it was generally applied to the rock sequences of England, the land of its birth, before it was recognized in Germany, the original home of mining and earth-science, be-

\footnotetext{
${ }^{1}$ ANnald OF Iowa, v. XI, p. 401, July, 1914.
} 
EVOLUTION OF THE GENERAL ROCK SCHEME IN IOWA.

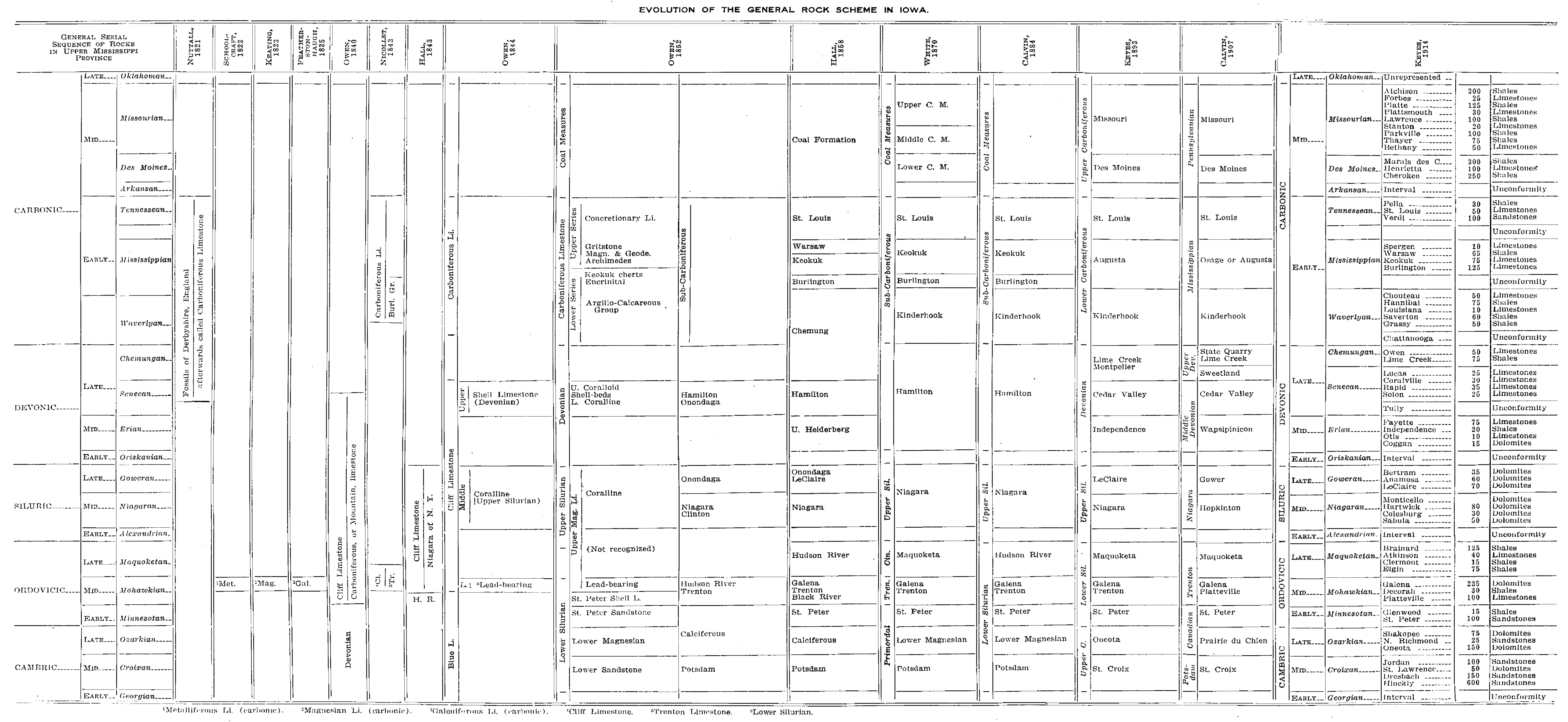


fore it was grasped in France, where paleontology long prior had taken its rise, the Smithian law was, in a remarkable way and under still more remarkable circumstances, skillfully. and successfully put into practice in the remotest part of the youngest of the continents, where the doctrine of the older science had not yet penetrated.

It is the second great forward movement in geological science in this country that recently awakens attention anew. This is the introduction, in the middle of the last century, but for the first time happily and accurately in this country, of the then new English system of classification of the rock formations of our globe. The resolution of the old Wernerian medley of transition rocks into an orderly arrangement of naturally succeeding groups was distinctly an English achievement. Through the unremitting labors of the. great English geologists of the first half of the Nineteenth century, the main subdivisions of the enigmatical Paleozoics were first differentiated and delimited in a manner that has stood the test of time.

It was Dr. David Dale Owen, who, with a nicety that would do ample credit to any savant of today, first transferred the English scheme to America, selecting Iowa wherein to fit the plan. This was during the years 1840 to 1850 .

Several unusual circumstances conspired to introduce and to adapt satisfactorily the English scheme of rock classification in the wild, unsettled interior of the North American continent before it was accomplished anywhere else even within the borders of the more thickly populated Atlantic states. Among these factors the early work of Nuttall gave singular and telling impulse to the movement. The lateness of settlement of the region made the latter too remote to receive at an earlier time any influence of the passing Wernerian conceptions which were already long potent east of the Appalachians. The great importance of Dubuque as a mining center, then the most productive camp in the whole country, where annually were produced nine-tenths of all the lead of this country and one-tenth of the entire world supply, marked Iowa a region for immediate and special scien. tific investigation by the Federal government. The principal 
workers in the western field chanced to be English-trained men, and hence were practically familiar with the latest advancements in the science in England and the continent. Singularly enough the general rock-succession in the upper Mississippi valley is strikingly like that of England; and this fact could not fail to impress investigators fresh from that field. Lastly, the so-called New York System had been found to be faulty. Tn reality it represented a conception that was already a superseded notion. In the attempt to establish it in the east the true taxonomic relationships of the formations themselves were completely lost sight of.

The expansion of the Iowa scheme has, therefore, more than state-wide bearing. Its interest is even more than continental in extent. It is, indeed, of world-wide significance, The development of the idea is concisely expressed in the accompanying diagram. Nuttall's great discovery is represented. The introduction and growth of the European scheme is shown. There is also foreshadowed the third great advance which, although initiated a couple of decades ago and is only today just beginning to be accepted throughout the world, may stand forth, fifty to one hundred years hence, as a recent writer states, as one of the half dozen great new thoughts characterizing Twentieth Century science.

\section{JOHN L. BURNS.}

On Wednesday after the battle commenced, John L. Burns, an old citizen of this place, shouldered his musket and went out by himself to meet the rebels. $\mathrm{He}$ advanced to the hottest of the scene and blazed away with his old musket until he fell wounded in the leg, side and arm. He reached his home, and though severely wounded, it is hoped he will soon recover. Patriotism and bravery like this is worthy of record in the annals of this war.-Gettysburg, Pa.-Star and Banner, July 9, 1863.

[The above paragraph is doubtless the record of the incident which prompted Bret Harte to write the popular poem, "Jolnn Burns of Gettysburg."-EDitor.] 
Copyright of Annals of Iowa is the property of State of Iowa, by \& through the State Historical Society of Iowa and its content may not be copied or emailed to multiple sites or posted to a listserv without the copyright holder's express written permission. However, users may print, download, or email articles for individual use. 